\title{
Orexin-A regulates cell apoptosis in human H295R adrenocortical cells via orexin receptor type 1 through the AKT signaling pathway
}

\author{
XIAOCEN CHANG ${ }^{1}$, YUYAN ZHAO ${ }^{2}$, SHUJING JU ${ }^{1}$ and LEI GUO ${ }^{1}$ \\ Departments of ${ }^{1}$ Orthopedic Surgery and ${ }^{2}$ Endocrinology, First Affiliated Hospital, \\ China Medical University, Shenyang, Liaoning 110001, P.R. China
}

Received August 15, 2014; Accepted April 30, 2015

DOI: $10.3892 / \mathrm{mmr} .2015 .4381$

\begin{abstract}
Numerous studies have demonstrated the ability of orexin-A to regulate adrenocortical cells through the mitogen-activated protein kinase signaling pathway. In the present study, human $\mathrm{H} 295 \mathrm{R}$ adrenocortical cells were exposed to orexin-A $\left(10^{-10}-10^{-6} \mathrm{M}\right)$, with orexin receptor type $1\left(\mathrm{OX}_{1}\right.$ receptor) antagonist SB334867 or AKT antagonist PF-04691502. It was found that orexin-A stimulated H295R cell proliferation, reduced the pro-apoptotic activity of caspase-3 to protect against apoptotic cell death and increased cortisol secretion. Furthermore, phospho-AKT protein was increased by orexin-A. SB334867 (10 $\left.{ }^{-6} \mathrm{M}\right)$ and PF-04691502 $\left(10^{-6} \mathrm{M}\right)$ abolished the effects of orexin-A $\left(10^{-6} \mathrm{M}\right)$. These results suggested that the orexin- $\mathrm{A} / \mathrm{OX}_{1}$ receptor axis has a significant pro-survival function in adrenal cells, which is mediated by AKT activation. Further studies investigating the effects of orexin-A-upregulation may further elucidate the diverse biological effects of orexin-A in adrenal cells.
\end{abstract}

\section{Introduction}

Orexin-A and -B, also known as hypocretin-1 and -2, are encoded by a single gene and are derived from a common pre-propeptide $(1,2)$. The orexins are hypothalamic peptides implicated in sleep regulation, wakefulness, neuroendocrine homeostasis and feeding (3). More recent studies have demonstrated that the expression of the orexins is not restricted to the hypothalamus only, but that they are also expressed in peripheral tissues, including adrenal glands, the gastrointestinal tract and the pancreas (2).

Correspondence to: Professor Yuyan Zhao, Department of Endocrinology, First Affiliated Hospital, China Medical University, 155 Nanjing North Street, Shenyang, Liaoning 110001, P.R. China E-mail: g572@sina.com

Key words: orexin-A, orexin receptor type 1, apoptosis, AKT signaling pathway, adrenocortical cells
The activities of orexins are mediated by two membrane-bound G-protein-coupled receptors, orexin receptor type $1\left(\mathrm{OX}_{1}\right.$ receptor) and $-2\left(\mathrm{OX}_{2}\right.$ receptor), which are found in the central nervous system as well as in peripheral organs, including the hypothalamus, adrenal glands, the gastrointestinal tract and the pancreas (3-7). It has been recently shown that the activated $\mathrm{OX}_{1}$ receptor may exist in a homodimeric form (8). Orexin-A is a high-affinity agonist of the $\mathrm{OX}_{1}$ receptor, whereas orexin-B has significantly lower affinity for the $\mathrm{OX}_{1}$ receptor. Previous studies have shown that orexin-A stimulates the proliferation, contributes to the viability and protects against apoptotic cell death in 3T3-L1 fibroblasts and adrenocortical cells $(9,10)$. Of note, a recent study has demonstrated the ability of orexins to induce apoptosis in cancer cells in culture (11). $\mathrm{OX}_{1}$ receptor is expressed in cancer cells and was shown to be responsible for regulating the apoptotic effects of orexins $(12,13)$. Thus, it has been proposed that pro-apoptotic activity is an intrinsic property of orexin receptors (14).

$\mathrm{AKT}$, also known as protein kinase $\mathrm{B}(\mathrm{PKB})$, is a $56-\mathrm{kDa}$ member of the AGC serine/threonine protein kinase family. AKT was first characterized for its function in regulating cell proliferation and survival, which may be due to the direct or indirect effects of AKT on a large number of cellular proteins. $\mathrm{AKT}$ is mainly regulated through the activation of the second messenger, phospholipid kinase phosphatidylinositol 3-kinase (PI3K). Abundant evidence indicated that AKT is a key regulator of multiple cell survival mechanisms (15). For example, AKT can contribute to the inactivation of the tumor suppressor p53 (promoter of apoptosis), in response to cellular stress, possibly by the phosphorylation of $\mathrm{Mdm} 2$, which is a direct regulator of p53 (16). The pro-apoptotic B-cell lymphoma-2 (Bcl-2) family member Bcl-2-associated death domain (17), as well as Forkhead box and cyclic adenosine monophosphate-response element binding protein transcription factors can be phosphorylated and inactivated by AKT $(18,19)$. Furthermore, AKT phosphorylates and activates mammalian target of rapamycin (mTOR) in response to growth factors and oncogenes (20-22). AKT leads to cell cycle dysregulation and inhibition of pro-apoptotic pathways that are typical hallmarks of human tumors (23). As such, AKT has key roles in tumor cell survival (24), proliferation (25), growth (26), apoptosis (27), 
migration (27) and polarity (28). Recent studies have shown that AKT might be a potential therapeutic target for innovative treatments of cancer, and some AKT inhibitors are now being tested in clinical trials in cancer patients $(29,30)$.

To date, compelling evidence has indicated an interaction of the orexin system with the hypothalamus-pituitary-adrenal axis on a central as well as peripheral level (14). More recent studies have shown that orexins $\left(10^{-8}-10^{-6} \mathrm{M}\right)$, acting through orexin receptors, can regulate the viability and proliferation of adrenal cells $(30,31)$. These effects can be mediated through multiple signaling pathways, including protein kinase $\mathrm{A}$, protein kinase $\mathrm{C}$, and mitogen-activated protein kinase (MAPK) cascade-dependent mechanisms $(31,32)$. However, little is known regarding the ability of orexins to activate the $\mathrm{PKB} / \mathrm{AKT}$ pathway in adrenal cells.

In the present study, human NCI-H295R cells were used as an adrenocortical cell model (33). A cell proliferation assay was performed to assess the effect of orexin-A on adrenocortical cell growth. Furthermore, the apoptotic rate and caspase-3 activation were examined to assess the effect of orexin-A on protecting against apoptosis. In addition, to ascertain the involvement of the PKB/AKT pathway, the present study examined the expression of total AKT and phosphorylated AKT after cells were treated with serial concentrations of orexin-A and inhibitors. The results provided evidence for a functional role of orexin-A in human adrenocortical cells via an $\mathrm{OX}_{1}$ receptor-stimulated AKT signaling pathway.

\section{Materials and methods}

Reagents. The orexin-A and caspase-3 colorimetric assay kits were obtained from Sigma-Aldrich (St Louis, MO, USA). RPMI 1640 medium and fetal bovine serum were purchased from Gibco Life Technologies (Carlsbad, CA, USA). The AKT inhibitor PF-04691502 was purchased from Selleck (Houston, TX, USA). The $\mathrm{OX}_{1}$ receptor-specific antagonist SB334867 was obtained from Tocris (Minneapolis, MA, USA). The cell Proliferation ELISA brodmodeoxyuridine (BrdU) colorimetric kit was purchased from Roche Diagnostics (Basel, Switzerland). Total-AKT rabbit polyclonal antibody (ab8805), phospho- (p-)AKT (T308+S473) rabbit polyclonal antibody (ab66134) and $\mathrm{OX}_{1}$ receptor rabbit polyclonal antibody (ab68718) were obtained from Abcam (Cambridge, UK). $\beta$-Actin mouse monoclonal antibody (C4) (sc-47778) was obtained from Santa Cruz Biotechnology, Inc. (Dallas, TX, USA). The Cortisol Express ELISA kit was purchased from Alpco (Paris, France). The Annexin V-fluorescein isothiocyanate (FITC) apoptosis detection kit was obtained from BD Biosciences (Franklin Lakes, NJ, USA).

Cell culture. Human H295R adrenocortical cells were obtained from the American Type Culture Collection (Manassas, VA, USA) and maintained in RPMI 1640 medium supplemented with $10 \%$ (wt/vol) fetal bovine serum (Gibco Life Technologies), L-glutamine, penicillin (50 $\mu \mathrm{g} / \mathrm{ml})$ and streptomycin (100 $\mu \mathrm{g} / \mathrm{ml}$; Xianfeng, Shanghai, China). The cells were grown in a humidified atmosphere containing $5 \%$ $\mathrm{CO}_{2}$ at $37^{\circ} \mathrm{C}$. Prior to each experiment, cells were grown in petridishes in serum-free medium for $24 \mathrm{~h}$. The next day, cells $\left(4 \times 10^{3}\right.$ cells/well in 96 -well plates or $5 \times 10^{5}$ cells/well in six-well plates) were treated with various concentrations of orexin-A $\left(0,10^{-10}, 10^{-8}\right.$ or $10^{-6} \mathrm{M}$; Sigma-Aldrich) or $10^{-6} \mathrm{M}$ orexin-A with SB334867 and/or PF-04691502.

Cell proliferation assays. H295R adrenocortical cells were seeded $\left(2 \times 10^{3}\right.$ cells/well) in 96-well plates and cultured for $24 \mathrm{~h}$. To synchronize the cells, they were serum-deprived for $24 \mathrm{~h}$ and then treated with the respective test agents for a further $24 \mathrm{~h}$. BrdU incorporation into DNA was measured by the Cell Proliferation ELISA BrdU colorimetric kit (Roche Diagnostics). The cells were incubated with BrdU fresh media at $37^{\circ} \mathrm{C}$ and $5 \% \mathrm{CO}_{2}$ for $12 \mathrm{~h}$ and fixed with $200 \mu \mathrm{l}$ of fixative/denaturing solution for $30 \mathrm{~min}$ at room temperature. The peroxidase-conjugated BrdU antibody was then added to each well followed by incubation for $1 \mathrm{~h}$. After washing thoroughly with cold phosphate-buffered saline (PBS) three times, the bound peroxidase-conjugated BrdU antibody was quantified with peroxidase substrate tetramethylbenzidine. Finally, the BrdU absorbance was measured at $440 \mathrm{~nm}$ using an ELISA plate reader (BioTek Instruments, Winooski, VT, USA). A control without cells was used to measure the background absorbance of the medium and was subtracted from the results.

Annexin V/propidium iodide (PI) assays for apoptosis. For Annexin V/PI assays, H295R cells were stained with Annexin V-FITC and PI, and evaluated for apoptosis by flow cytometry according to the manufacturer's instructions (BD Biosciences). Cells were treated with various concentrations of orexin-A in the absence of serum for $48 \mathrm{~h}$. Briefly, $1 \times 10^{5}$ cells were washed twice with PBS and stained with $5 \mu 1$ Annexin V-FITC and $10 \mu \mathrm{l}$ PI in $500 \mu \mathrm{l}$ binding buffer for $15 \mathrm{~min}$ at room temperature in the dark. Quantification of apoptosis was determined by counting the number of cells stained by FITC-labeled Annexin V. The apoptosis of cells was detected using the Annexin V/PI Apoptosis Detection kit by fluorescence-assisted cell sorting. The data was quantified and analyzed using FACScan flow cytometry and Cellquest software, version 3.3 (Becton Dickinson, San Jose, CA, USA).

Early apoptotic cells were identified by negative PI staining and positive FITC-Annexin V staining, while cells in late apoptosis or necrotic cells were FITC-Annexin $V$ - and PI-positive.

Activity of caspase-3 in H295R cells. H295R cells were cultured in serum-free medium in six-well plates $\left(1.5 \times 10^{5}\right.$ cells/well). Culture medium was then replaced with fresh culture medium with or without orexins. After $24 \mathrm{~h}$, caspase-3 activity was assessed using a Caspase-3 Colorimetric Assay kit.

Assessment of cortisol. For cortisol release experiments, H295R cells were cultured in six-well plates until the cells were $\sim 80-85 \%$ confluent. Cells were serum-starved overnight and then washed and incubated in fresh serum-free media containing various concentrations of orexin-A and the respective inhibitors for $24 \mathrm{~h}$. At the end of the incubation period, the supernatant was preserved by immediate snap-freezing in liquid nitrogen until cortisol measurements were performed. Cortisol levels were assessed using the ELISA kit according to the manufacturer's instructions. 
Reverse transcription quantitative polymerase chain reaction (RT-qPCR). Total RNA was extracted from H295R cells using TRIzol reagent (Invitrogen Life Technologies). Following spectrophotometric quantification, $1 \mu \mathrm{g}$ total RNA was reverse-transcribed into cDNA using the PrimeScript ${ }^{\mathrm{TM}}$ RT reagent kit with gDNA Eraser (Takara Bio Inc., Otsu, Japan) according to the manufacturer's instructions. cDNA aliquots corresponding to equal amounts of RNA were used for the quantification of mRNA by qPCR using the LightCycler 96 real time quantitative PCR detection system (Roche, Indianapolis, IN, USA). The following specific primers were used: $\mathrm{OX}_{1}$ receptor forward, 5'-TGCGGCCAACCCTATCATCTA-3' and reverse, (5'-ACCGGCTCTGCAAGGACAA-3'. As an internal control for reverse transcription and reaction efficiency, amplification of GAPDH mRNA was performed in parallel for each sample. The following specific primers were used: GAPDH forward, 5'-GGCACAGTCAAGGCTGAGAATG-3' and reverse, 5'-ATGGTGGTGAAGACGCCAGTA-3'. The PCR reactions were performed using the following conditions: $95^{\circ} \mathrm{C}$ for $30 \mathrm{sec}$, then 40 cycles of $95^{\circ} \mathrm{C}$ for $5 \mathrm{sec}, 60^{\circ} \mathrm{C}$ for $30 \mathrm{sec}$ and $95^{\circ} \mathrm{C}$ for $15 \mathrm{sec}$. All primers and TaqMan probes specific to $\mathrm{OX}_{1}$ receptor and GAPDH were designed using Primer Premier 5.0 software (Premier Biosoft International, Palo Alto, CA, USA). Relative changes in gene expression were calculated using the equation: Relative changes in gene expression $=2-\Delta \Delta \mathrm{CT}$ where $\Delta \mathrm{Ct}=\mathrm{Ct}$ target $-\mathrm{Ct}$ GAPDH and $\Delta \Delta \mathrm{Ct}=\Delta \mathrm{Ct}$ Unmethylated $-\Delta \mathrm{Ct}$ control.

Protein preparation and western blot analysis. H295R cells were washed with cold PBS and harvested in radioimmunoprecipitation assay buffer (Beyotime Institute of Biotechnology, Haimen, China) containing protease inhibitors. Cell lysates were incubated on ice for $30 \mathrm{~min}$ and were collected and centrifuged at $12,000 \mathrm{xg}$ for $10 \mathrm{~min}$ at $4^{\circ} \mathrm{C}$. The supernatants were collected and mixed with $5 \mathrm{X}$ loading buffer (Beyotime Institute of Biotechnology), then denatured by boiling for 10 min. Samples were separated by $10 \%$ SDS-PAGE and transferred to polyvinylidene difluoride membranes (Beyotime Institute of Biotechnology) at $60 \mathrm{~V}$ for $2.5 \mathrm{~h}$ in a transfer buffer containing $20 \mathrm{mM}$ Tris, $150 \mathrm{mM}$ glycine and $20 \%$ methanol (Beyotime Institute of Biotechnology). Membranes were incubated in non-fat dry milk for $120 \mathrm{~min}$ at room temperature and then washed three times with Tris-buffered saline containing Tween 20 (TBST) for $30 \mathrm{~min}$. The membranes were incubated with primary antibody against $\mathrm{OX}_{1}$ receptor at a 1:250 dilution or phospho/total-AKT and $\beta$-actin at a 1:1,000 dilution in TBST overnight at $4^{\circ} \mathrm{C}$. The membranes were washed and incubated with a secondary goat anti-rabbit immunoglobulin $\mathrm{G}$ antibody at a 1:2,000 dilution in TBST for $1.5 \mathrm{~h}$ at room temperature, and then washed three times with TBST for $30 \mathrm{~min}$. Protein was visualized using the enhanced chemiluminescence method with an ECL detection kit (Beyotime Institute of Biotechnology). Band densities were measured using Quantity-One (v 4.6.2) software (Bio-Rad Laboratories, Hercules, CA, USA).

Statistical analysis. Values are expressed as the mean \pm standard error of the mean and differences between values were analyzed by one-way analysis of variance. $\mathrm{P} \leq 0.05$ was considered to indicate a statistically significant difference between
A

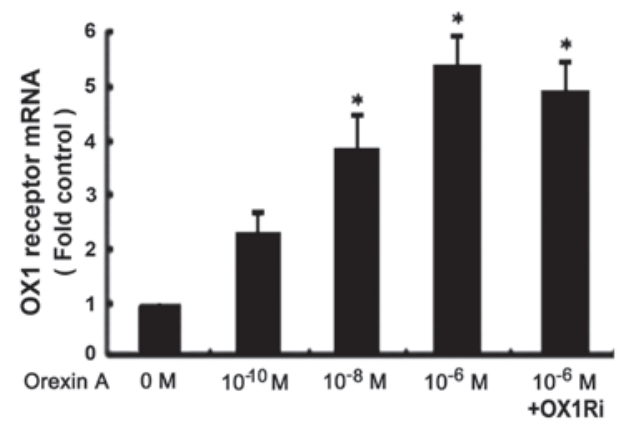

B
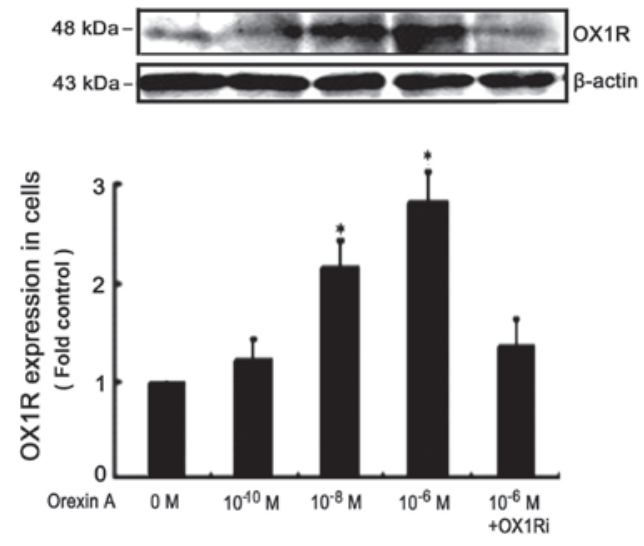

Figure 1. Effects of orexin-A on $\mathrm{OX}_{1} \mathrm{mRNA}$ and protein expression. Cells were exposed to orexin- $\mathrm{A}$ at concentrations of $0,10^{-10}, 10^{-8}$ and $10^{-6} \mathrm{M}$ for $24 \mathrm{~h}$ Another group was treated with $10^{-6} \mathrm{M}$ orexin- $\mathrm{A}$ in the presence of $\mathrm{OX}_{1} \mathrm{Ri}$ $\left(10^{-6} \mathrm{M}\right)$. The expression of $\mathrm{OX}_{1}$ receptor (A) mRNA and (B) protein were assessed using polymerase chain reaction and western blot analysis, respectively. Values are expressed as the mean \pm standard error of the mean based on triplicate determinations from a representative experiment. " $\mathrm{P}<0.05$ vs. control. $\mathrm{OX}_{1}$ receptor, orexin 1 receptor; $\mathrm{OX}_{1} \mathrm{Ri}, \mathrm{OX}_{1}$ receptor antagonist SB334867.

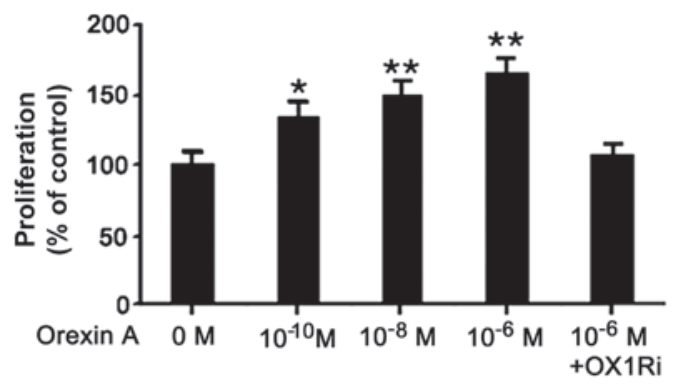

Figure 2. Proliferation of H295R cells after incubation with orexin-A. Cells were exposed to orexin-A at concentrations of $0,10^{-6}, 10^{-8}$ and $10^{-10} \mathrm{M}$ for $24 \mathrm{~h}$. In addition, a separate group of cells was treated with $10^{-6} \mathrm{M}$ orexin-A in the presence of $\mathrm{OX}_{1} \mathrm{Ri}\left(10^{-6} \mathrm{M}\right)$ for $24 \mathrm{~h}$. Proliferation was determined by the bromodeoxyuridine assay. Values are expressed as the mean \pm standard error of the mean based on quadruplicate determinations from a representative experiment. ${ }^{*} \mathrm{P}<0.05 ;{ }^{* *} \mathrm{P}<0.01$ vs. control. $\mathrm{OX}_{1} \mathrm{Ri}, \mathrm{OX}_{1}$ receptor antagonist SB334867.

values. Statistical analysis was performed using the SPSS 15.0 software package (SPSS, Inc., Chicago, IL, USA).

\section{Results}

Effects of orexin-A on $O X_{1}$ receptor protein expression in H295R cells. PCR analysis demonstrated that $\mathrm{OX}_{1}$ receptor mRNA was expressed in H295R cells (Fig. 1A). Orexin-A 


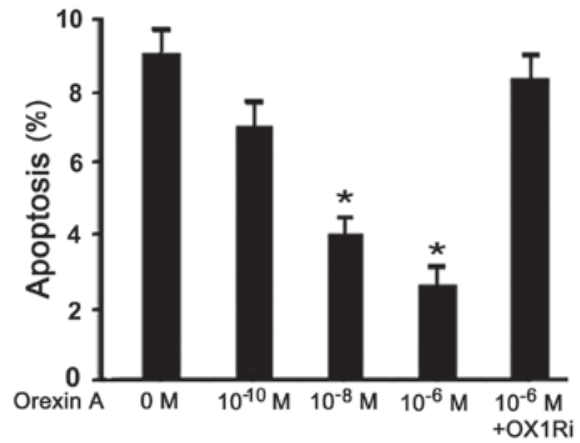

Figure 3. Orexin-A protects H295R cells from apoptosis. Cells were exposed to orexin-A at concentrations of $0,10^{-6}, 10^{-8}$ and $10^{-10} \mathrm{M}$ for $24 \mathrm{~h}$, or cells were treated with $10^{-6} \mathrm{M}$ orexin- $\mathrm{A}$ in the presence of $\mathrm{OX}_{1} \mathrm{Ri}\left(10^{-6} \mathrm{M}\right)$. Apoptosis was assessed using Annexin V/propidium iodide staining and flow cytometric analysis. Values are expressed as the mean \pm standard error of the mean based on quadruplicate determinations from a representative experiment. ${ }^{\mathrm{P}}<0.05$ vs. control. $\mathrm{OX}_{1} \mathrm{Ri}, \mathrm{OX}_{1}$ receptor antagonist SB334867.

A

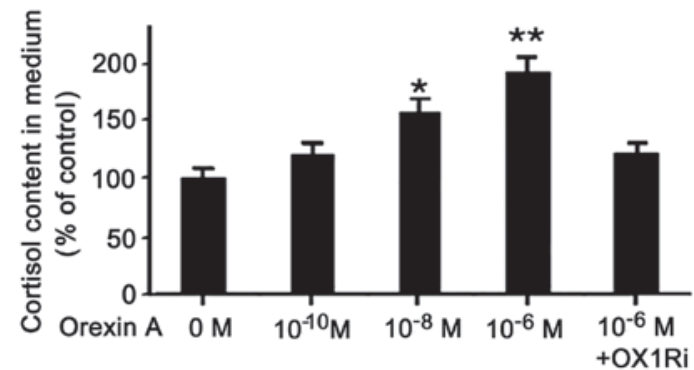

B

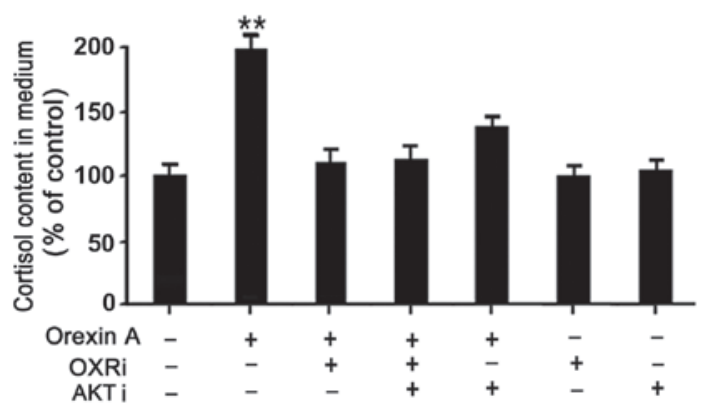

Figure 4. Effects of orexin-A on cortisol secretion in H295R cells. (A) Cells were exposed to orexin-A at concentrations of $0,10^{-10}, 10^{-8}$ and $10^{-6} \mathrm{M}$ for $24 \mathrm{~h}$, or to (B) $10^{-6} \mathrm{M}$ orexin-A in the presence of $\mathrm{OX}_{1} \mathrm{Ri}\left(10^{-6} \mathrm{M}\right)$ and/or AKTi $\left(10^{-6} \mathrm{M}\right)$. Cortisol content was assessed using an ELISA kit. Values are expressed as the mean \pm standard error of the mean based on triplicate determinations from a representative experiment. " $\mathrm{P}<0.05 ;{ }^{* *} \mathrm{P}<0.01$ vs. control. $\mathrm{OX}_{1} \mathrm{Ri}, \mathrm{OX}_{1}$ receptor antagonist SB334867; AKTi, AKT antagonist PF-04691502.

$\left(10^{-10}, 10^{-8}\right.$ and $\left.10^{-6} \mathrm{M}\right)$ induced a significant increase of $\mathrm{OX}_{1}$ receptor mRNA levels in a dose-dependent manner (Fig. 1A). Similarly, orexin-A treatment increased $\mathrm{OX}_{1}$ receptor protein expression in H295R cells in a dose-dependent manner, with $10^{-6} \mathrm{M}$ orexin-A being the most potent (Fig. 1B). This increase in expression was attenuated in the presence of $10^{-6} \mathrm{M}$ SB334867, a high-affinity, non-peptidic $\mathrm{OX}_{1}$ receptor-specific antagonist (Fig. 1B). However, the increase of $\mathrm{OX}_{1}$ receptor mRNA levels was not significantly abolished in the presence of SB334867, compared with that in the group treated with $10^{-6} \mathrm{M}$ orexin-A only (Fig. $1 \mathrm{~A} ;{ }^{*} \mathrm{P}<0.05$, vs. control).

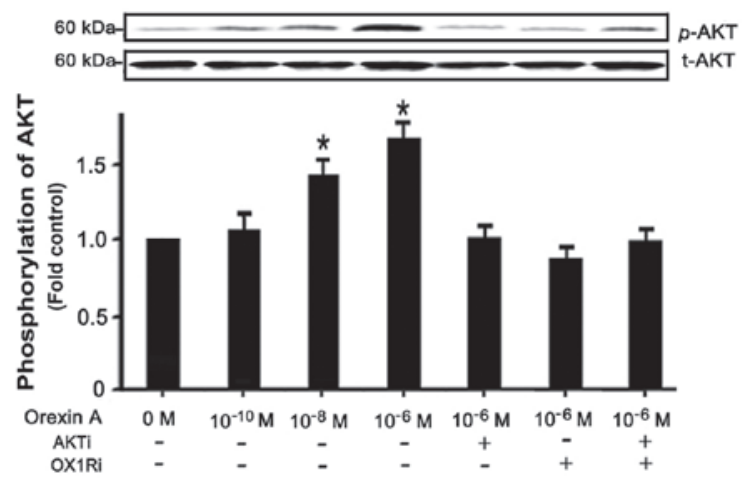

Figure 5. Orexin-A improves the proliferation of $H 295 \mathrm{R}$ cells via the $\mathrm{OX}_{1}$ receptor-mediated AKT signaling pathway. Cells were stimulated with orexin-A at concentrations of $0,10^{-6}, 10^{-8}$ and $10^{-10} \mathrm{M}$ for $20 \mathrm{~min}$ in the presence of $\mathrm{AKTi}\left(10^{-6} \mathrm{M}\right), \mathrm{OX}_{1} \mathrm{Ri}\left(10^{-6} \mathrm{M}\right)$ or the combination of the two. Autophosphorylation of p-AKT was evaluated along with the total protein activation. $\beta$-actin protein expression was used as an internal control for equal protein loading. Protein activation was measured by western blot analysis. Values are expressed as the mean \pm standard error of the mean based on quintuplicate determinations from a representative experiment. ${ }^{*} \mathrm{P}<0.05$ vs. control. $\mathrm{OX}_{1} \mathrm{Ri}, \mathrm{OX}_{1}$ receptor antagonist SB334867; AKTi, AKT antagonist PF-04691502; p/t-AKT, phosphorylated/total AKT.

Effects of orexin-A on the proliferation of H295R cells. To determine the effects of orexin-A on cell proliferation, H295R cells were stimulated with various concentrations of orexin-A $(0$, $10^{-6}, 10^{-8}$ and $10^{-10} \mathrm{M}$ ) or $10^{-6} \mathrm{M}$ orexin-A along with $10^{-6} \mathrm{M}$ $\mathrm{OX}_{1}$ receptor antagonist SB334867 and subjected to a BrdU incorporation assay. The cell proliferation-promoting effect of orexin-A was dose-dependent. Concentrations of $10^{-6}, 10^{-8}$ and $10^{-10} \mathrm{M}$ of orexin-A led to 1.6-, 1.5- and 1.3-fold increases, respectively, in cell proliferation, which was attenuated in the presence of SB334867 (Fig. 2; ${ }^{*} \mathrm{P}<0.05,{ }^{* *} \mathrm{P}<0.01$, vs. control).

Orexin-A protects $H 295 R$ cellular apoptosis. Orexin-A treatment $\left(10^{-6}, 10^{-8}\right.$ and $\left.10^{-10} \mathrm{M}\right)$ resulted in a decrease in the apoptotic index as measured by Annexin V/PI assays. Concentrations of $10^{-8}$ and $10^{-6} \mathrm{M}$ orexin-A led to a significant 0.56- and 0.72-fold decrease in the rate of apoptosis of H295R cells compared to that of the control $(\mathrm{P}<0.05)$ (Fig. 3); however, it failed to protect cells against apoptosis in the presence of SB334867 (Fig. 3; ${ }^{\mathrm{P}}<0.05$, vs. control).

Effects of orexin-A on cortisol secretion by H295R cells. After starving overnight in serum-free media, H295R cells were incubated with various concentrations $\left(0,10^{-10}, 10^{-8}\right.$ and $10^{-6} \mathrm{M}$ ) orexin-A, and the cells were treated with $10^{-6} \mathrm{M}$ orexin-A and $\mathrm{OX}_{1}$ receptor antagonist SB334867 $\left(10^{-6} \mathrm{M}\right)$. Dose-dependent effects of orexin-A on the cortisol content in the medium were identified from the cell culture supernatants. The effect of $10^{-6}$ and $10^{-8} \mathrm{M}$ orexin-A reached statistical significance, increasing cortisol secretion by 2 - and 1.5 -fold, respectively, compared to that of the control $(\mathrm{P}<0.01)$. This effect was attenuated in the presence of SB334867 $\left(10^{-6} \mathrm{M}\right)$ (Fig. 4A). Furthermore, the AKT antagonist PF-04691502 $\left(10^{-6} \mathrm{M}\right)$, the $\mathrm{OX}_{1}$ receptor antagonist SB334867 $\left(10^{-6} \mathrm{M}\right)$, as well as their combination abolished the relative increases in the cortisol secretion in response to orexin-A (Fig. 4B; ${ }^{*} \mathrm{P}<0.05,{ }^{* *} \mathrm{P}<0.01$, vs. control). 


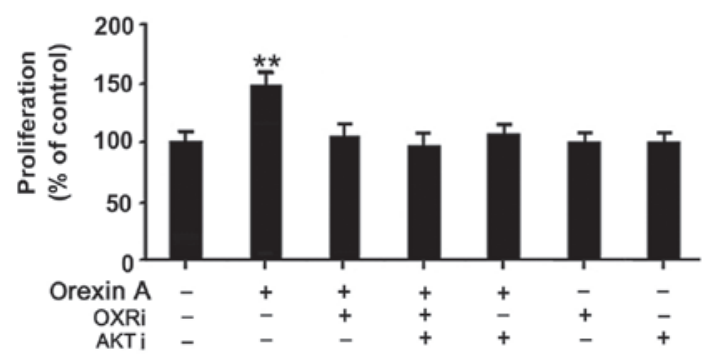

Figure 6. Effects of orexin-A on the proliferation of H295R cells via stimulation of the AKT signaling pathway. Cells were exposed to orexin-A at concentrations of 0 or $10^{-6} \mathrm{M}$ for $24 \mathrm{~h}$ in the presence or absence of AKTi, $\mathrm{OX}_{1} \mathrm{Ri}$, or a combination of the two. In addition, cells were incubated with $\mathrm{AKTi}$ and $\mathrm{OX}_{1} \mathrm{Ri}$ without orexin-A treatment for $24 \mathrm{~h}$. Proliferation was determined by the bromodeoxyuridine assay. Values are expressed as the mean \pm standard error of the mean based on quintuplicate determinations from a representative experiment. " $\mathrm{P}<0.05 ;{ }^{* * *} \mathrm{P}<0.01$ vs. control. $\mathrm{OX}_{1} \mathrm{Ri}, \mathrm{OX}_{1}$ receptor antagonist SB334867; AKTi, AKT antagonist PF-04691502.

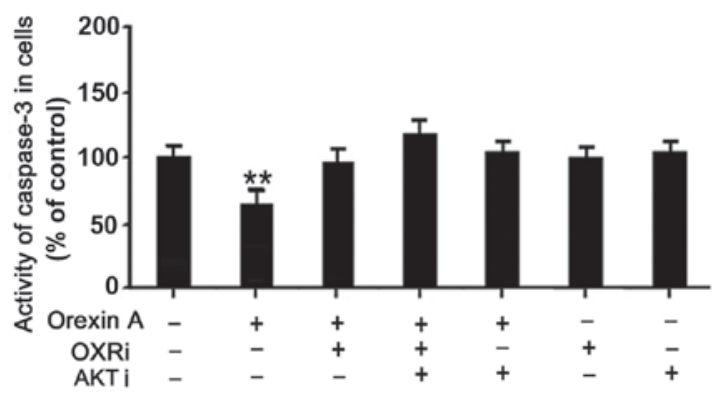

Figure 7. Activity of caspase-3 in H295R cells. Cells were cultured with or without $10^{-6} \mathrm{M}$ orexin-A for $24 \mathrm{~h}$ in the presence or absence of AKTi, OXRi or the combination of the two. Caspase-3 activity was assessed using a Caspase-3 Colorimetric Assay kit. Values are expressed as the mean \pm standard error of the mean based on triplicate determinations from a representative experiment. ${ }^{* * *} \mathrm{P}<0.01$ vs. control. $\mathrm{OX}_{1} \mathrm{Ri}, \mathrm{OX}_{1}$ receptor antagonist SB334867; AKTi, AKT antagonist PF-04691502.

Orexin-A improves proliferation of $H 295 R$ cells via an $O X_{1}$ receptor-stimulated AKT signaling pathway. As the $\mathrm{PI} 3 \mathrm{~K} / \mathrm{AKT}$ signaling pathway is involved in cell survival signaling, the present study examined whether orexin-A-stimulation of H295R cells induced activation of AKT. The results confirmed a specific increase in p-AKT protein in H295R cells treated with $10^{-6} \mathrm{M}$ orexin-A, which was 1.6 -fold increased compared with that in the untreated control (Fig. 5). Total AKT levels, however, remained unaffected by orexin-A treatment. Furthermore, the AKT antagonist PF-04691502 $\left(10^{-6} \mathrm{M}\right)$, the $\mathrm{OX}_{1}$ receptor antagonist SB334867 $\left(10^{-6} \mathrm{M}\right)$, as well as their combination, abolished the relative increases in AKT activation in response to orexin-A (Fig. 5). These results suggested that the regulation of the AKT pathway was closely associated with orexin-A-induced proliferation via the $\mathrm{OX}_{1}$ receptor $\left({ }^{*} \mathrm{P}<0.05\right.$, vs. control).

Effects of orexin-A on proliferation of H295R cells via activation of the AKT signaling pathway. To confirm the involvement of the AKT signaling pathway in orexin-A-mediated proliferation in $\mathrm{H} 295 \mathrm{R}$ cells, the BrdU incorporation assay was employed to test cell proliferation. The proliferation of H295R cells was significantly increased following incubation with $10^{-6} \mathrm{M}$ orexin-A. However, these effects were blocked by AKT antagonist PF-04691502, $\mathrm{OX}_{1}$ receptor antagonist SB334867, or their combination. In comparison, cell proliferation was not affected by the AKT antagonist or the $\mathrm{OX}_{1}$ receptor antagonist in the absence of orexin-A (Fig. 6). These results suggested that AKT participates in orexin-A-induced stimulation of proliferation in $\mathrm{H} 295 \mathrm{R}$ cells $\left({ }^{*} \mathrm{P}<0.05,{ }^{* *} \mathrm{P}<0.01\right.$, vs. control).

Effects of orexin-A on caspase-3 activation in H295R cells. To test whether the activation of the caspase pathway was involved in the orexin-A-mediated anti-apoptotic effect in H295R cells, caspase-3 activity (part of the cell death cascade) was measured. Orexin-A treatment $\left(10^{-6} \mathrm{M}\right)$ caused a significant decrease in caspase-3 activity. This effect was blunted in the presence of PF-04691502 $\left(10^{-6} \mathrm{M}\right)$, SB334867 (10-6 M), and the with two inhibitors administered simultaneously. These results indicated that the anti-apoptotic effect of orexin-A was mediated, at least in part, through caspase-3 (Fig. 7).

\section{Discussion}

The present study demonstrated that orexin-A had a crucial effect on the proliferation and apoptosis of human H295R adrenocortical cells through the $\mathrm{OX}_{1}$ receptor and the AKT signaling pathway. In agreement with studies performed on adrenocortical cells $(31,32)$, the present study reported that orexin-A regulates the biological activity of $\mathrm{H} 295 \mathrm{R}$ cells via the $\mathrm{OX}_{1}$ receptor. In particular, it was identified that orexin-A activates the MAPK signaling cascades in adrenocortical cells. It was also demonstrated that the effects of orexin-A on survival and apoptosis via the $\mathrm{OX}_{1}$ receptor are mediated through an additional signaling pathway, namely the AKT pathway.

Orexin-A is considered to be a high-affinity agonist of the $\mathrm{OX}_{1}$ receptor, whereas orexin-B has a significantly lower affinity for the $\mathrm{OX}_{1}$ receptor. However, the two orexins show similar affinities for the $\mathrm{OX}_{2}$ receptor $(5,34)$. The $\mathrm{OX}_{1}$ receptor is expressed in cancer cells and was shown to be responsible for the pro-apoptotic effect of orexins (14). In the present study, the effects of orexin-A on $\mathrm{OX}_{1}$ receptor expression were investigated. The increase in $\mathrm{OX}_{1}$ receptor expression was orexin- $\mathrm{A}$ concentration-dependent, and the increase induced by $10^{-6}$ and $10^{-8} \mathrm{M}$ orexin-A was significant, with $10^{-6} \mathrm{M}$ orexin-A having the most potent effect.

In agreement with studies performed on 3T3-L1 fibroblasts and adrenocortical cells $(9,10)$, the present study found that orexin-A stimulated H295R cell proliferation, protected against apoptotic cell death and promoted the release of cortisol. These effects were blunted by co-treatment with the $\mathrm{OX}_{1}$ receptor antagonist SB334867. Consistent with previous studies, the effects of promoting proliferation and cortisol release were dose-dependent. High concentrations of orexin-A $\left(10^{-6}\right.$ and $\left.10^{-8} \mathrm{M}\right)$ led to a statistically significant decrease in the rate of apoptosis of $\mathrm{H} 295 \mathrm{R}$ cells, with the concentration of $10^{-6} \mathrm{M}$ of orexin-A being the most potent. All these findings demonstrate that orexin-A and its receptor are closely associated with the survival and function of adrenal cortical cells. Following further research, orexin-A and its receptor may become a therapeutic target for regulating adrenal cortical 
dysfunction. It is important to note, however, that certain studies discovered that orexin-A was a potent pro-apoptotic peptide in colon cancer cell lines and neuroblastoma cells (12). Therefore, it is possible that the cell type is an important factor contributing to the physiological effects of orexin-A-induced proliferation and apoptosis. Future studies may further determine these cell type-specific effects.

Numerous previous studies have focused on the effects of the MAPK pathway, which is one pathway via which the biological effects of orexin-A are mediated $(9,10,35)$. The AKT signaling pathway is often activated via mechanisms controlling cell growth and survival. Increased AKT activation or dysregulation due to elevated AKT activation, as well as indirect changes in AKT regulation, result in enhanced cell survival signaling, which is a common feature in various forms of human cancers $(36,37)$. These changes directly or indirectly regulate apoptosis (38). The present study investigated the association between the regulation of apoptosis by orexin-A and the AKT pathway. $10^{-6}$ and $10^{-8} \mathrm{M}$ orexin-A led to statistically significant decreases in the rate of apoptosis of $\mathrm{H} 295 \mathrm{R}$ cells, and this effect was confirmed by a reduction in caspase- 3 activation. Caspase- 3 is a key molecule involved in the execution of apoptosis and acts downstream in the apoptotic cascade (39). Other caspase pathways may be assessed in future studies in order to investigate whether caspases involved in the extrinsic (receptor-mediated) pathway of apoptosis are also implicated. Orexin-A failed to protect H295R cells against apoptosis in the presence of PF-04691502, a TP-competitive PI3K/mTOR dual inhibitor. The PF-04691502 inhibitor reduced phosphorylation of AKT T308 and AKT S473 and inhibited cell proliferation.

The present study has shed new light on the mechanisms whereby orexin-A mediates the biological activity of adrenocortical cells. The findings demonstrated that orexin-A regulates H295R cell proliferation and survival, promotes the release of cortisol, reduces the pro-apoptotic activity of caspase- 3 and also protects against apoptotic death via the AKT pathway. While more comprehensive and specific mechanisms remain to be elucidated, the present study has provided the first evidence of orexin-A regulating biological functions of human H295R adrenocortical cells via the AKT signaling pathway. Together with further studies utilizing orexin receptor inhibitors, the results of the present study may provide a novel and promising target for the treatment of diseases caused by orexin in the adrenal gland.

\section{Acknowledgements}

The present study was supported by the National Natural Science Foundation of China (grant nos. 30872724, 81071460 and 81271996). The authors would like to thank the Hospital Laboratory Center affiliated to China Medical University for kindly providing the equipment used in the present study.

\section{References}

1. de Lecea L, Kilduff TS, Peyron C, Gao X, Foye PE, Danielson PE, Fukuhara C, Battenberg EL, Gautvik VT, Bartlett FS II, Frankel WN, et al: The hypocretins: Hypothalamus-specific peptides with neuroexcitatory activity. Proc Natl Acad Sci USA 95: 322-327, 1998.
2. Voisin T, Rouet-Benzineb P, Reuter N and Laburthe M: Orexins and their receptors: Structural aspects and role in peripheral tissues. Cell Mol Life Sci 60: 72-87, 2003.

3. Korczynski W, Ceregrzyn M, Matyjek R, Kato I, Kuwahara A, Wolinski J and Zabielski R: Central and local (enteric) action of orexins. Physiol Pharmacol 57 (Suppl 6): 17-42, 2006.

4. Sakurai T: Orexins and orexin receptors: Implication in feeding behavior. Regul Pept 85: 25-30, 1999.

5. Sakurai T, Amemiya A, Ishii M, Matsuzaki I, Chemelli RM, Tanaka H, Williams SC, Richardson JA, Kozlowski GP, Wilson S, Arch JR, et al: Orexins and orexin receptors: a family of hypothalamic neuropeptides and $\mathrm{G}$ protein-coupled eceptors that regulate feeding behavior. Cell 92: 573-585, 1998.

6. Kukkonen JP, Holmqvist T, Ammoun S and Åkerman KE: Functions of the orexinergic/hypocretinergic system. Am J Physiol Cell Physiol 283: C1567-C1591, 2002.

7. Randeva HS, Karteris E, Grammatopoulos D and Hillhouse EW: Expression of orexin-A and functional orexin type 2 receptors in the human adult adrenals: Implications for adrenal function and energy homeostasis. J Clin Endocrinol Metab 86: 4808-4813, 2001.

8. Xu TR, Ward RJ, Pediani JD and Milligan G: The orexin OX1 receptor exists predominantly as a homodimer in the basal state: Potential regulation of receptor organization by both agonist and antagonist ligands. Biochem J 439: 171-183, 2011.

9. Kim MK, Park HJ, Kim SR, Choi YK, Shin HK, Jeon JH, Jang HO, Yun I, Bae SK and Bae MK: Angiogenic role of orexin-A via the activation of extracellular signal-regulated kinase in endothelial cells. Biochem Biophys Res Commun 403: 59-65, 2010.

10. Ramanjaneya M, Conner AC, Chen J, Kumar P, Brown JE, Jöhren O, Lehnert H, Stanfield PR and Randeva HS: Orexin-stimulated MAP kinase cascades are activated through multiple G-protein signalling pathways in human $\mathrm{H} 295 \mathrm{R}$ adrenocortical cells: diverse roles for orexins A and B. J Endocrinol 202: 249-261, 2009.

11. Voisin T, El Firar A, Fasseu M, Rouyer-Fessard C, Descatoire V, Walker F, Paradis V, Bedossa P, Henin D, Lehy T and Laburthe M: Aberrant expression of OX1 receptors for orexins in colon cancers and liver metastases: An openable gate to apoptosis. Cancer Res 71: 3341-3351, 2011.

12. Rouet-Benzineb P, Rouyer-Fessard C, Jarry A, Avondo V, Pouzet C, Yanagisawa M, Laboisse C, Laburthe $\mathrm{M}$ and Voisin T: Orexins acting at native $\mathrm{OX}(1)$ receptor in colon cancer and neuroblastoma cells or at recombinant OX (1) receptor suppress cell growth by inducing apoptosis. J Biol Chem 279: 45875-45886, 2004.

13. Laburthe $\mathrm{M}$ and Voisin T: The orexin receptor OX1R in colon cancer: a promising therapeutic target and a new paradigm in $\mathrm{G}$ protein-coupled receptor signalling through ITIMs. Br J Pharmacol 165: 1678-1687, 2012.

14. Kagerer SMand Johren O: Interactions of orexins/hypocretins with adrenocortical functions. Acta Physiol (Oxf) 198: 361-432, 2010.

15. Martelli AM, Tabellini G, Bressanin D, Ognibene A, Goto K, Cocco L and Evangelisti C: The emerging multiple roles of nuclear Akt. Biochim Biophys Acta 1823: 2168-2178, 2012.

16. Zhou BP, Liao Y, Xia W, Zou Y, Spohn B and Hung MC: HER-2/neu induces p53 ubiquitination via AKT-mediated MDM2 phosphorylation. Nat Cell Biol 3: 973-982, 2001.

17. Datta SR, Dudek H, Tao X, Masters S, Fu H, Gotoh Y and Greenberg ME: AKT phosphorylation of BAD couples survival signals to the cell-intrinsic death machinery. Cel191:231-241,1997.

18. Brunet A, Bonni A, Zigmond MJ, Lin MZ, Juo P, Hu LS, Anderson MJ, Arden KC, Blenis J and Greenberg ME: AKT promotes cell survival by phosphorylating and inhibiting a Forkhead transcription factor. Cell 96: 857-868, 1999.

19. Burgering BM and Kops GJ: Cell cycle and death control: long live Forkheads. Trends Biochem Sci 27: 352-360, 2002.

20. Fu L, Kim YA, Wang X, Wu X, Yue P, Lonial S, Khuri FR and Sun SY: Perifosine inhibits mammalian target of rapamycin signaling through facilitating degradation of major components in the mTOR axis and induces autophagy. Cancer Res 69: 8967-8976, 2009.

21. Hay N and Sonenberg N: Upstream and downstream of mTOR. Genes Dev 18: 1926-1945, 2004.

22. Richardson CJ, Schalm SS and Blenis J: PI3-kinase and TOR: PIKTORing cell growth. Semin Cell Dev Biol 15: 147-159, 2004.

23. Steelman LS, Chappell WH, Abrams SL, Kempf RC, Long J, Laidler P, Mijatovic S, Maksimovic-Ivanic D, Stivala F, Mazzarino MC, Donia M, et al: Roles of the Raf/MEK/ERK and $\mathrm{PI} 3 \mathrm{~K} / \mathrm{PTEN} / \mathrm{AKT} / \mathrm{mTOR}$ pathways in controlling growth and sensitivity to therapy-implications for cancer and aging. Aging (Albany NY) 3: 192-222, 2011. 
24. Hsieh AC, Truitt ML and Ruggero D: Oncogenic AKTivation of translation as a therapeutic target. Br J Cancer 105: 329-336, 2011.

25. Sale EM and Sale GJ: Protein kinase B: signalling roles and therapeutic targeting. Cell Mol Life Sci 65: 113-127, 2008.

26. Blandino-Rosano M, Chen AY, Scheys JO, Alejandro EU, Gould AP, Taranukha T, Elghazi L, Cras-Méneur C and Bernal-Mizrachi E: mTORC1 signaling and regulation of pancreatic $\beta$-cell mass. Cell Cycle 11: 1892-1902, 2012.

27. Cheng GZ, Zhang W and Wang LH: Regulation of cancer cell survival, migration and invasion by twist: AKT2 comes to interplay. Cancer Res 68: 957-960, 2008.

28. Buttrick GJ and Wakefield JG: PI3-K and GSK-3: AKT-ing together with microtubules. Cell Cycle 7: 2621-2625, 2008.

29. Meuillet EJ: Novel inhibitors of AKT: assessment of a different approach targeting the pleckstrin homology domain. Curr Med Chem 18: 2727-2742, 2011.

30. Bartholomeusz C and Gonzalez-Angulo AM: Targeting the PI3K signaling pathway in cancer therapy. Expert Opin Ther Targets 16: 121-130, 2012.

31. Ramanjaneya M, Conner AC, Chen J, Kumar P, Brown JE, Jöhren O, Lehnert H, Stanfield PR and Randeva HS: Orexin-stimulated MAP kinase cascades are activated through multiple G-protein signalling pathways in human H295R adrenocortical cells:diverse roles for orexins A and B. J Endocrinol 202: 249-261, 2009.

32. Ramanjaneya M, Conner AC, Chen J, Stanfield PR and Randeva HS: Orexins stimulate steroidogenic acute regulatory protein expression through multiple signaling pathways in human adrenal H295R cells. Endocrinology 149: 4106-4115, 2008.
33. Rainey WE, Saner K and Schimmer BP: Adrenocortical cell lines. Mol Cell Endocrinol 228: 23-38, 2004.

34. Ammoun S, Holmqvist T, Shariatmadari R, Oonk HB Detheux M, Parmentier M, Åkerman KE and Kukkonen JP: Distinct recognition of OX1 and OX2 receptors by orexin peptides. J Pharmacol Exp Ther 305: 507-514, 2003.

35. Kim MS, Yoon CY, Jang PG, Park YJ, Shin CS, Park HS, Ryu JW, Pak YK, Park JY, Lee KU, Kim SY, et al: The mitogenic and antiapoptotic actions of ghrelin in 3T3-L1 adipocytes. Mol Endocrinol 18: 2291-2301, 2004.

36. Li Y, Jiang Y, Wan Y,Zhang L, Tang W, Ma J, Wu S and Cheng W: Medroxyprogestogen enhances apoptosis of SKOV-3 cells via inhibition of the PI3K/AKT signaling pathway. J Biomed Res 27: 43-50, 2013.

37. Rajput S, Kumar BN, Sarkar S, Das S, Azab B, Santhekadur PK, Das SK, Emdad L, Sarkar D, Fisher PB and Mandal M: Targeted apoptotic effects of thymoquinone and tamoxifen on XIAP mediated AKT regulation in breast cssancer. PLoS One 8: e61342, 2013.

38. Skrzypski M, Kaczmarek P, Le TT, Wojciechowicz T, Pruszyńska-Oszmalek E, Szczepankiewicz D, Sassek M, Arafat A, Wiedenmann B, Nowak KW and Strowski MZ: Effects of orexin A on proliferation, survival, apoptosis and differentiation of 3T3-L1 preadipocytes into mature adipocytes. FEBS Lett 586: 4157-4164, 2012.

39. Cryns V and Yuan J: Protease to die for. Genes Dev 12: 1551-1570, 1998. 